\title{
WestVirginiaUniversity
}

THE RESEARCH REPOSITORY @ WVU

West Virginia Agricultural and Forestry Experiment

Davis College of Agriculture, Natural Resources

Station Bulletins

And Design

$1-1-1967$

\section{The response of hillside pastures to fertilizer applied by airplane}

G. A. Jung

John Allan Balasko

G. E. Toben

Follow this and additional works at: https://researchrepository.wvu.edu/ wv_agricultural_and_forestry_experiment_station_bulletins

\section{Digital Commons Citation}

Jung, G. A.; Balasko, John Allan; and Toben, G. E., "The response of hillside pastures to fertilizer applied by airplane" (1967). West Virginia Agricultural and Forestry Experiment Station Bulletins. 545.

https://researchrepository.wvu.edu/wv_agricultural_and_forestry_experiment_station_bulletins/499 @ WVU. It has been accepted for inclusion in West Virginia Agricultural and Forestry Experiment Station Bulletins by an authorized administrator of

The Research Repository @ WVU. For more information, please contact ian.harmon@mail.wvu.edu. 
West Virginia University Libraries

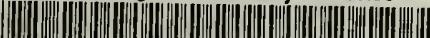

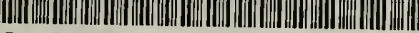

308021009521343 
Digitized by the Internet Archive in 2010 with funding from

Lyrasis Members and Sloan Foundation 


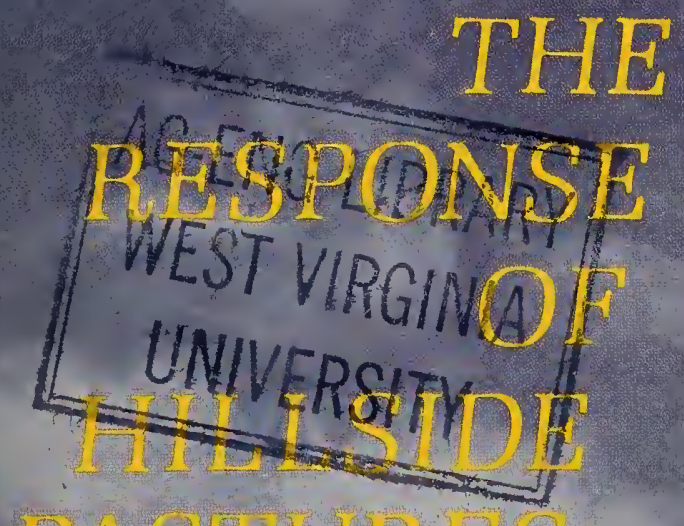

PASTURTE

\section{FERTLLZRR}

$$
\begin{gathered}
\text { APPLIED } \\
\text { BL }
\end{gathered}
$$

\section{ADRPLANE}

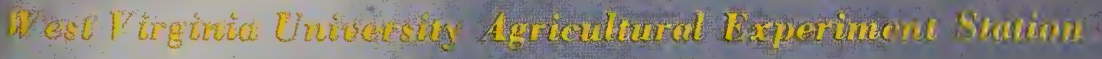




\section{THE AUTHORS}

Authors of The Response of Hillside Pastures to Fertilizer Applied by Airplane are G. A. Jung, Associate Agronomist; J. A. Balasko, graduate student in Agronomy; and G. E. Toben, Agricultural Economist.

\section{ACKNOWLEDGMENTS}

The authors deeply appreciate the cooperation received from the following farmers in Monongalia County, West Virginia on whose farms portions of this study were completed: Mr. J. D. Anderson, Mr. J. B. Dalton, Mr. Glen W. Hunter, Mr. Robert L. Kelly, Mr. Burkey Lilly (Garlow Farm), Mr. Junior Statler, Mr. Robert Straight, and Mr. Ralph J. Thomas.

They also express their appreciation to Mr. Rufus Reed and Mr. John Gorman, West Virginia Soil Conservation Service; Mr. Burkey Lilly, Monongalia County Cooperative Extension Agent; Dr. F. J. Olsen, formerly Extension Agronomist and Dr. A. L. Barr, Agricultural Economist, West Virginia University; and Dr. Paul Stangel, formerly of the Tennessee Valley Authority for their time and assistance in helping to initiate this study and to Dr. R. L. Reid for his assistance with the nutritive evaluation of the forage.

West Virginia University Agricultural Experiment Station College of Agriculture and Forestry

A. H. Vanlandingham, Director Morgantown 


\section{The Response of Hillside Pastures To Fertilizer Applied By Airplane}

G. A. JUNG, J. A. BALASKO, and G. E. TOBEN

\section{INTRODUCTION}

THE IMPORTANCE of pasture production in West Virginia is revealed in the 1964 census. Dairy, beef, and sheep enterprises accounted for 49 per cent of the value of farm products sold in West Virginia in 1964. The total land pastured in the State in that year was 2,875,249 acres, 54 per cent of the total land in farms. Excluding woodland pasture, there were $1,965,155$ acres of other pasture, only 16 per cent of which was classified as improved.

Most of the parent materials from which West Virginia soils were derived are relatively low in base and phosphorous content. During the soil development processes, the base content was depleted by leaching. Cropping following the removal of the forests further depleted plant nutrients. The land generally was utilized for pasture when erosion became a problem or when crop production became too low to be profitable. Even though West Virginia has been blessed with a climate ideally suited for the growth of many pasture grasses and legumes, agronomic studies over a 30 -year period clearly show that very little of this forage potential can be obtained without fertilization. Indeed, the major limiting factor in livestock farming in all of Appalachia today is fertilization.

Experiments conducted in West Virginia and elsewhere in the northeastern region of the United States have shown that pastures of desirable botanical composition can be attained through adequate liming, fertilization, and management. These pastures have a higher carrying capacity, more nearly satisfy the dietary needs of livestock, and therefore result in an improved quantity and quality of products produced. The fertilized pastures are more resistant to erosion losses and provide the best land-use for that portion of the farm which is not suitable for more intensive cropping. Pasture improvement through liming and fertilization is a "must" if profitable returns are to be realized, particularly on small farms, and if erosion losses are to be kept to a minimum.

Topography has been one reason for the limited fertilization of permanent pastures, but with aerial fertilization even topography is of a small consequence. This report summarizes the results of experiments designed to measure and evaluate the response of hill pastures, varying in soil type and soil $\mathrm{pH}$, to fertilizer applied from an airplane. 


\section{LITERATURE REVIEW}

Permanent pastures have been reported to respond favorably in yield to the application of lime, nitrogen, phosphorus, and potassium separately and in all combinations. Under West Virginia conditions, it has been shown by Odland et al. (18) and Robinson and Pierre (24) that applications of lime increased pasture yields. In later studies Schaller and Pohlman (27) found that phosphate efficiency was improved by lime. Pohlman and Cornell (21) evaluated the residual effects of lime and phosphorus applications on 44 pastures in Upshur County after one, two, or three years following treatment. On the average, the pastures had been treated with 1,396 pounds per acre of burnt lime, 2,067 pounds per acre of ground limestone, or 1,500 pounds per acre of marl and approximately 30 pounds per acre of phosphorus. Of the pastures receiving "adequate" treatment, 65 per cent of the treated plots had dry-matter yields greater than 50 per cent above those for the respective untreated plots. The authors noted that in many instances the treatments did not raise soil $\mathrm{pH}$ or available phosphorus content to levels considered optimum for the growth of bluegrass or white clover. Furthermore, treatment resulted in dry-matter yields 50 per cent above the yields from untreated pastures when many of the treated pastures had a soil $\mathrm{pH}$ less than 6.0 and the soil available prosphorus content was less than 40 pounds per acre.

Studies involving nitrogen fertilization of pastures have indicated significantly higher yields with nitrogen applications $(4,7,8,16,25,30)$. The increased yields attributed to a given level of nitrogen fertilizer can be affected by botanical composition $(8,16)$, time of application $(4,25)$, and climatic conditions $(8,16,25)$.

Several investigators have concluded from fertility studies with permanent pastures that phosphorus is the most limiting nutrient, and this is especially true where legumes are present $(7,16,24)$. Schaller and Pohlman (27) reported that the frequency of phosphate application was of far less importance than the total amount applied.

From many pasture experiments in Northeastern United States, workers have concluded that potassium is not the most limiting nutrient, and only after phosphorus has been supplied does potassium appear limiting. Brown el al. (4) pointed out that grazing animals return a considerable amount of potassium to the soil. Bear and Salter (1) reported that while 90 per cent of the West Virginia soils need lime, most of the soils are fairly well supplied with potassium. Bryan and Deatrick (6) working with 485 soil samples, including the agriculturally important soil series in West Virginia, found that all of the soils sampled averaged 1 per cent potassium or more. However, they did not determine how 
much of the potassium was available for plant growth. Robinson and Pierre (24) concluded that some West Virginia pastures would respond profitably to potassium fertilization, but that, in general, applications of lime and phosphorus would be most profitable.

Pierre et al. (19) concluded that the type of vegetation and lowcarrying capacity of most permanent pastures in West Virginia were due to soil acidity and depleted soil fertility. Soils with a pH of 5.8 or above supported good growth of Kentucky bluegrass and white clover, provided other factors were favorable. Odland et al. (18) reported considerable improvement in the quality of pastures which had received lime. Under certain conditions it has been found that nitrogen fertilization favors the growth of grasses at the expense of clover $(4,7,8,24,26,29)$, whereas clover replaced undesirable grasses and weeds in pastures treated with lime and/or superphosphate $(4,7,17,21,28)$. Odland et al. (18) and Brown et al. (4) found that lime and superphosphate were responsible for a greater increase in desirable species than superphosphate alone. Midgley and Weiser (14) pointed out that white clover is an important component of permanent pastures because it provides nitrogen for the grasses early in the spring, a more uniform distribution of seasonal yield, and reduces soil temperature. The importance of the latter was shown in another experiment in which soil temperatures above $60^{\circ} \mathrm{F}$. were found to inhibit rhizome and root growth of bluegrass (5).

In a description of the results of an experiment designed to compare the nutritive value of various forages, Swift et al. (31) expounded upon the interpretation of such experiments.

In attempting to compare the relative feeding value of various forages as reported in the literature, the investigator becomes keenly aware of the prevailing inequality of important factors influencing results. These factors, seldom if ever the same in any two cases, include weather, soil fertility, stage of maturity of the grass when cut, and conditions of drying for the production of hay.

Investigators have measured the content or digestibility of several plant constituents to evaluate the nutritive value of pastures. The quantities of protein obtained in pasture experiments were related to the amount of clover or nitrogen fertilization $(2,9,10,11,15,22,23,25,28$, 32). Brown and Munsell (3), Schaller et al. (28), and Vinall and Wilkins (32) found that when legumes were abundant, protein content of the forage was not increased with nitrogen fertilization. Several investigators $(2,13,15,20,32)$ reported increased amounts of phosphorus in herbage from pastures receiving phosphate fertilizer. Schaller et al. (28) have shown that pastures which were adjusted to a $\mathrm{pH}$ of 6.5 and treated with 500 pounds of 20 per cent superphosphate and 100 pounds of muriate of potash produced herbage with a higher content of calcium, phosphorus, and potassium than untreated pastures seven years after fertilizer applica- 
tion. Reid et al. (23), working with bluegrass, reported significant increases in protein content and digestibility of cellulose, protein, and dry matter as nitrogen applied to pasture increased from 60 pounds per acre to 240 pounds per acre. The increases were observed in the first growth but were not evident in aftermath growth. Over a 30-year period, Brown et al. (4) found that 80 pounds of phosphate per acre every three to five years increased the total digestible nutrients by 60 per cent over the unfertilized check which averaged 500 pounds of digestible nutrients per acre per year. Lime in addition to superphosphate accounted for a 109 per cent increase in the total digestible nutrients over the unfertilized check. Eheart and Pratt (9) found that with an annual application of 100 pounds of triple superphosphate and 50 pounds of nitrogen, protein digestibility increased while no change was observed in the digestibility of dry matter, crude fiber, ether extract, and nitrogen free-extract.

\section{EXPERIMENTAL PROCEDURE}

In the spring of 1963, areas of 20-30 per cent slope within nine permanent pastures located in Monongalia County were chosen to determine the effects of aerial fertilizer applications on hillside pasture. Within these areas three representative soil series of the county and three $\mathrm{pH}$ levels were present. The three $\mathrm{pH}$ levels were present within each soil series. The soil characteristics of the areas are presented in Table 1.

Six plots, each 4 feet square, were chosen within each of the areas and three were randomly assigned as control and three as treated. Plots designated as treated were fertilized from a fixed wing aircraft spreader adjusted to deliver 300 pounds of $14-56-0$ per acre. The amount of fertilizer being applied was determined by placing two fivegallon buckets at each site. The fertilizer was produced by the Tennessee Valley Authority and was applied as a composite mixture of 0-60-0 and 21-54-0 in a ratio of 1 to 2 respectively. Control plots were covered shortly before the fertilizer was spread with $8 \times 1$ ?-foot plastic sheets. The majority of the excess plastic was placed on the upper side of the slope above the control plots to minimize the possibility of nutrients being washed into the control plots. The plastic and fertilizer thereon were removed immediately after fertilization and wire cages $4 \times 4 \times 2$ feet were placed over all plots.

Plots were cut $1 \frac{11}{2}$ inches above the soil surface with a mower when the treated plots had accumulated 4 inches of growth. Climatic conditions permitted three cuttings during 1963 and five during 1964. Crude protein and digestible dry-matter determinations were made on forage produced during 1963 according to procedures described by Jung et al. (12). 


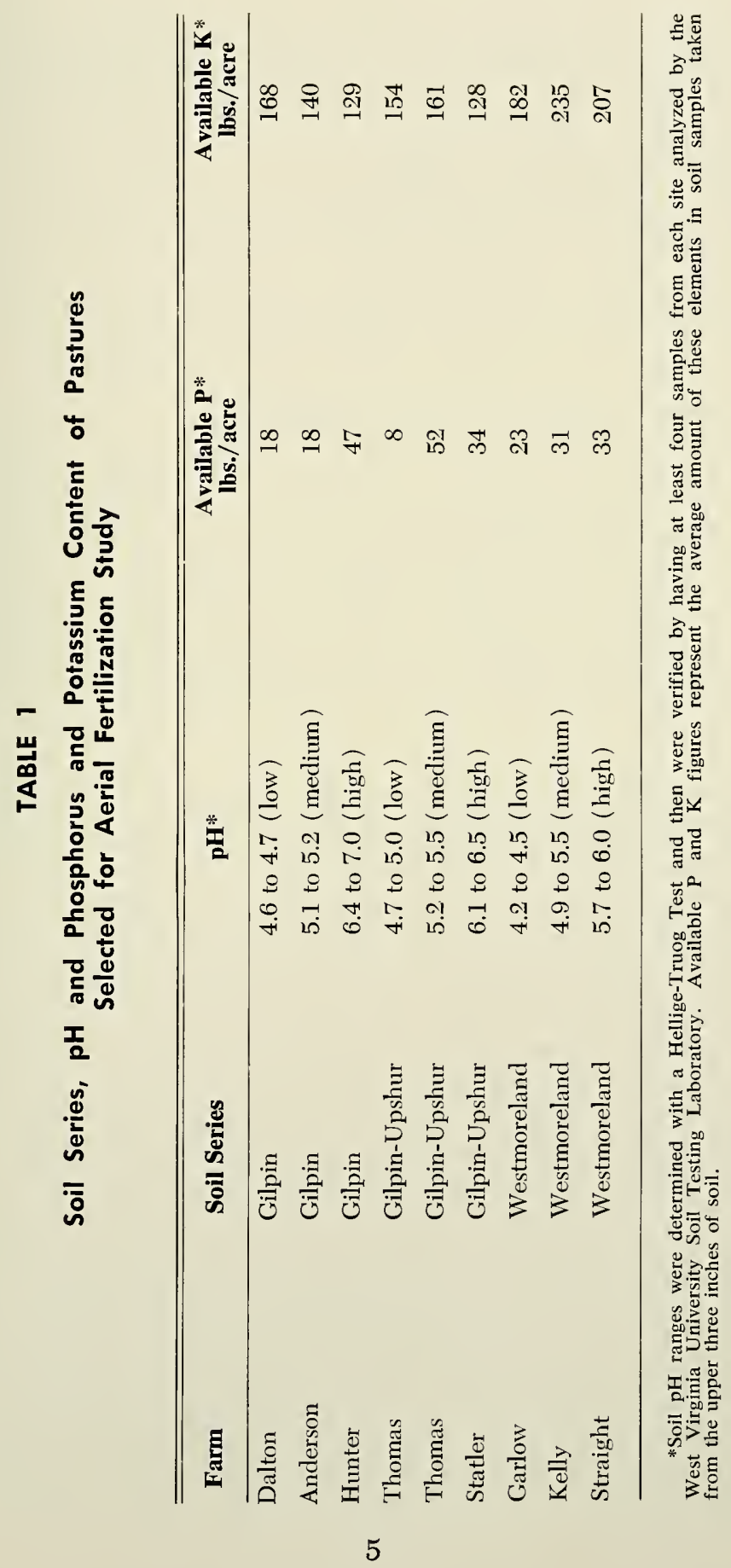


In order to assess the effect of the fertilizer application under more precise conditions, four plugs 3 inches in diameter and 4 inches deep were taken from each control area ( 12 plugs from each pasture). The plugs were chosen as uniformly as possible with respect to desirable species and plant density. The plugs were put in styrofoam containers and randomly placed under artificial light. Six of the 12 plugs from the untreated area of each pasture were randomly assigned as control and six as treated. Plugs designated as treated received the equivalent of 300 pounds of 14-56-0 fertilizer per acre in liquid form. The fertilizer was of the same type as that applied to the field plots. Temperature and moisture were approximately optimum for growth.

\section{RESULTS AND DISCUSSION}

The low amounts (less than 50 pounds per acre) of phosphorus available for plant growth at the initiation of this study (Table 1) are typical of phosphate levels found in most pastures in West Virginia. One objective, therefore, of the aerial fertilization program was to increase the amount of phosphorus available for plant growth. It was assumed that high levels (more than 90 pounds per acre) of phosphorus would encourage clover growth, which, in turn, would provide nitrogen for grasses. Potassium levels were not considered as limiting to plant growth in these pastures.

Dry-matter yields (weeds not included) harvested from fertilized and unfertilized pastures representing three soil series, each with three $\mathrm{pH}$ levels, are presented in Table 2 . Increased yields of forage with fertilization were observed for each cutting (data not presented) throughout the 1963 season. An average increase of 103 per cent in dry-matter yield was obtained for fertilized plots over unfertilized plots even though there was a moisture deficiency (6.3 inches less than normal) during the 1963 growing season (Table 3 ). Significant increases in yield between the treated and control plots were observed on six of the nine pastures. Significant increases did not occur on the medium $\mathrm{pH}$ Gilpin soil, the low $\mathrm{pH}$ Gilpin-Upshur soil, and the low $\mathrm{pH}$ Westmoreland soil; however, increases of 65,117 , and 34 per cent, respectively, were observed. Variation in plant density, kinds of species, and rate of fertilizer application from plot to plot resulted in low precision; hence, large differences in amounts of dry matter per acre were needed for significance. On the average, all three soil series responded to fertilization, but no significant differences in yield were noted among soil series. Significant increases in yield were obtained for fertilization at all soil $\mathrm{pH}$ levels. The average vield was significantly higher with the fertilized high $\mathrm{pH}$ soil than with the fertilized low or medium $\mathrm{pH}$ soils, whereas no differences were noted among yields for control plots. 
TABLE 2

Yields of Weed-Free Dry Matter from Fertilized and Unfertilized Pastures Representing Three Soil Series and Three pH Levels

\begin{tabular}{ll|c|c|c|c}
\hline \multirow{2}{*}{ Soil } & \multirow{2}{*}{$\mathbf{p H}$} & \multicolumn{4}{c}{ Dry-Matter Yields (Tons per acre) } \\
\cline { 3 - 6 } & & \multicolumn{3}{|c|}{$\mathbf{1 9 6 3}$} & \multicolumn{2}{c}{1964} \\
\hline Gilpin & Low & $.81 \mathrm{bc}^{*}$ & $.43 \mathrm{def}$ & $.63 \mathrm{efg}$ & $.33 \mathrm{fg}$ \\
Gilpin & Medium & $.66 \mathrm{bcd}$ & $.40 \mathrm{def}$ & $.78 \mathrm{def}$ & $.85 \mathrm{de}$ \\
Gilpin & High & $.70 \mathrm{bcd}$ & $.34 \mathrm{ef}$ & $1.21 \mathrm{abcd}$ & $.73 \mathrm{defg}$ \\
Gilpin-Upshur & Low & $.65 \mathrm{bcde}$ & $.30 \mathrm{ef}$ & $1.00 \mathrm{bcde}$ & $.65 \mathrm{efg}$ \\
Gilpin-Upshur & Medium & $.56 \mathrm{cde}$ & $.19 \mathrm{f}$ & $.75 \mathrm{def}$ & $.59 \mathrm{efg}$ \\
Gilpin-Upshur & High & $1.26 \mathrm{a}$ & $.66 \mathrm{bcd}$ & $1.47 \mathrm{ab}$ & $.86 \mathrm{de}$ \\
Westmoreland & Low & $.47 \mathrm{def}$ & $.35 \mathrm{def}$ & $.29 \mathrm{fg}$ & $.22 \mathrm{~g}$ \\
Westmoreland & Medium & $.96 \mathrm{ab}$ & $.32 \mathrm{ef}$ & $1.44 \mathrm{abc}$ & $.71 \mathrm{defg}$ \\
Westmoreland & High & $.86 \mathrm{bc}$ & $.39 \mathrm{def}$ & $1.66 \mathrm{a}$ & $.95 \mathrm{cde}$
\end{tabular}

Averages:

Gilpin

Gilpin-Upshur

.72 a

$.39 \mathrm{~b}$

$.87 \mathrm{ab}$

$.64 \mathrm{~b}$

Westmoreland

.82 a

$.38 \mathrm{~b}$

1.07 a

$.69 \mathrm{~b}$

$.77 \mathrm{a}$

$.35 \mathrm{~b}$

$1.13 \mathrm{a}$

$.63 \mathrm{~b}$

Low

Medium

High

All Pastures
$.64 \mathrm{~b}$

$.73 \mathrm{~b}$

.94 a

.77 a
$.36 \mathrm{c}$

$.30 \mathrm{c}$

$.46 \mathrm{c}$

$.38 \mathrm{~b}$
$.64 \mathrm{~cd}$

$.40 \mathrm{~d}$

$.98 \mathrm{~b}$

$.71 \mathrm{bc}$

$1.45 \mathrm{a}$

$.85 \mathrm{bc}$

* Data followed by a common letter are not significantly different. Comparisons may be made within each year, with averages considered separately.

On the average, 1964 dry-matter yields were higher than those of 1963. This was a result of a more favorable season with respect to rainfall (Table 3) and an earlier first cutting date. The percentage increase in yield due to treatment, however, was higher (10:3 vs. 58) in 1963 than in 1964 (Table 2). Lack of nitrogen probably was the reason for the smaller response, because there was not an abundance of clover in most plots during 1964 and little or no carry-over of nitrogen from the previous year. This hypothesis was tested by studying the relationship between dry-matter yield and percentage of clover in each treated and untreated 


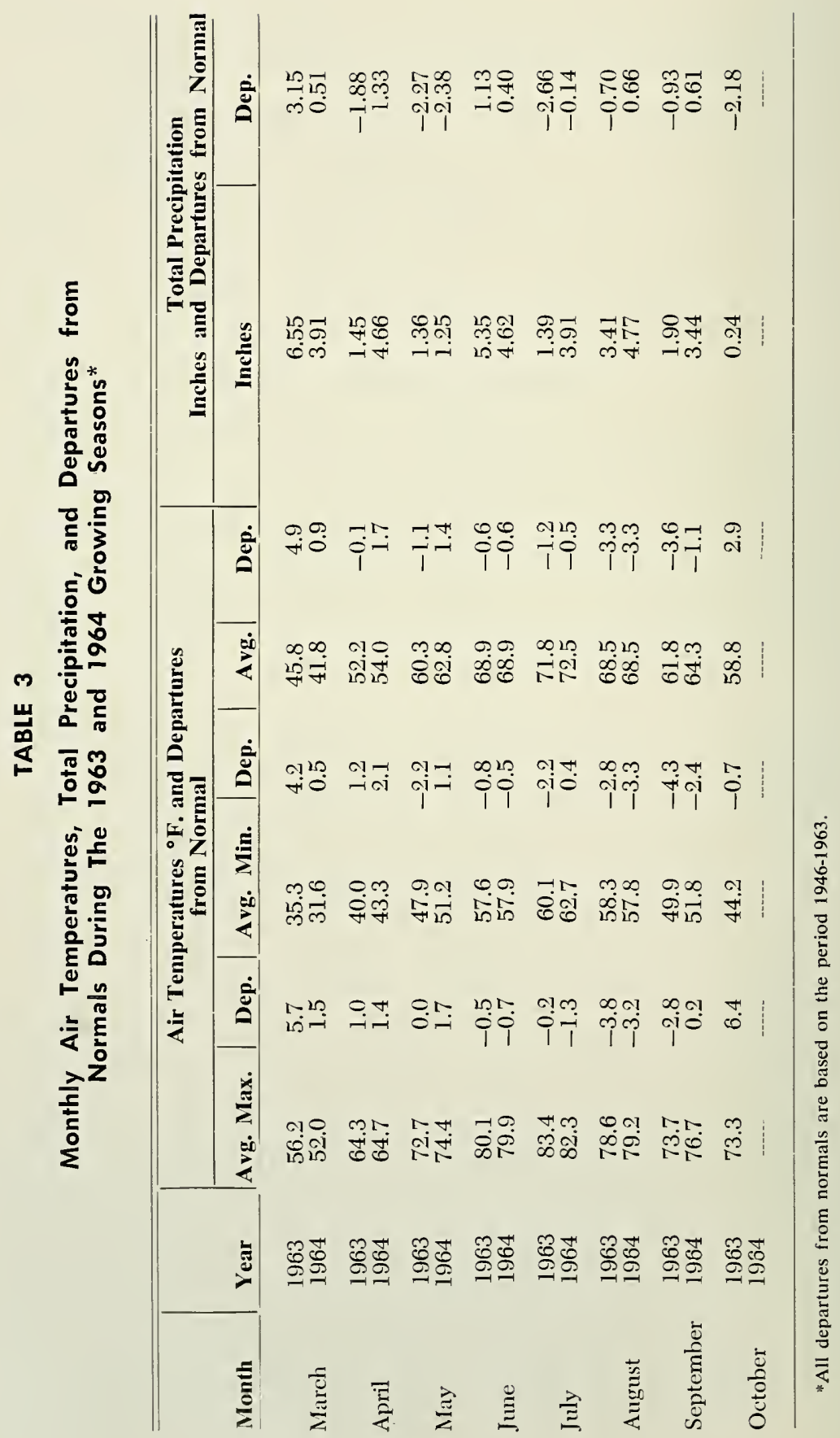


pasture. The relationship was found to be highly significant ( 1 per cent level). In both seasons the greatest percentage increase in dry-matter yields occurred at midseason and the least percentage increase in the latter part of the season (data not presented). Lower total dry-matter yields were harvested in 1964 than in 1963 from the low pH Gilpin soil and the low pH Westmoreland soil. Both of these pastures were undergrazed at the beginning of the experiment; therefore, large amounts of excess growth were included in the first cutting of 1963. This was not the case in 1964 and the corresponding growth response from the fertilizer and more desirable climatic conditions were not large enough to equal that of the excess growth, thus lower yields resulted. In 1964 only the yields from the treated plots on the high $\mathrm{pH}$ Gilpin-Upshur soil and the medium and high $\mathrm{pH}$ Westmoreland soil were significantly larger than those from the control plots. Again in this year due to large variance among pastures, other increases of large proportions were not significantly different. Average yields for fertilized and control plots representing the three ioil series indicated that the fertilizer effect was significant for the Gilpin-Upshur and Westmoreland soils and that yield was not affected by soil series. With regard to $\mathrm{pH}$ levels, only the high $\mathrm{pH}$ soils responded significantly to fertilization. Increased yields were noted with increasing soil $\mathrm{pH}$ levels of the fertilized plots and between the low $\mathrm{pH}$ soils and the medium or high $\mathrm{pH}$ soils of the control plots.

If yields for the two-year period are considered, the response to fertilization resulted in yield equivalents from 21 to 1.56 tons of hay per acre. On the average, the Gilpin soil was least responsive (.64 tons of hay per acre), the Gilpin-Upshur soil was intermediate in response (.92 tons of hay per acre), and the Westmoreland soil was most responsive ( 1.04 tons of hay per acre) to fertilization. Increased yields were noted with an increase in soil $\mathrm{pH}$. At the low soil $\mathrm{pH}$ the equivalent of .59 tons of hay per acre were produced, whereas the respective yields for the medium soil $\mathrm{pH}$ and high soil $\mathrm{pH}$ were .79 and 1.23 tons of hay per acre. While these trends did exist, it should be pointed out that yields from two pastures (medium $\mathrm{pH}$ Gilpin soil and low $\mathrm{pH}$ Westmoreland soil) lowered the averages considerably. An explanation for the small responses for these two pastures is offered later in the discussion.

The importance of botanical composition in each pasture was illustrated vividly in this study. In both years the largest increase in yield due to fertilization occurred on the medium $\mathrm{pH}$ Westmoreland soil. This pasture rated as one of the best with respect to desirable species (Table 4). On the other hand, the low $\mathrm{pH}$ Westmoreland soil gave the least response to fertilization in 1963 . Of the nine pastures, this pasture had the highest percentage of weeds and the least amount of clover (Table * (dry matter X 1.137) 
4). Further investigation of this pasture showed that some Guernsey soil was present as well as Westmoreland soil. The Guernsey soil, because of its structure, probably limited clover establishment. The least response in 1964 to the fertilizer (applied in 1963) was noted for the medium $\mathrm{pH}$ Gilpin soil. In both years, the control plots in this pasture had a higher percentage of clover than the treated plots; and therefore, the effects of the clover may have tended to equalize the effects of the fertilizer. These pastures provide good examples of the close association between botanical composition and productivity.

Forage of more desirable botanical composition was harvested from the treated plots than from the control plots (Table 4). Bluegrass, orchardgrass, and clover made up most of the desirable species; and on the average, treated plots contained higher percentages of these species and lower percentages of other grasses and weeds than the control plots. Desirable species, harvested from treated plots when compared with those harvested from control plots, made up 15 per cent more of the total forage harvested in 1963 and 20 per cent more in 1964 (data not presented). When all plots are considered for both years, bluegrass, orchardgrass, and clover represented 47 per cent of the total forage produced on the Gilpin soil. These same species represented 54 per cent of the forage produced on the Gilpin-Upshur soil and 55 per cent of that produced on the Westmoreland soil. The plots on the high $\mathrm{pH}$ Gilpin soil, medium and high $\mathrm{pH}$ Gilpin-Upshur soil, and high $\mathrm{pH}$ Westmoreland soil were the only ones where appreciable amounts of orchardgrass were present. Bluegrass, orchardgrass, and clover made up 40 per cent of the forage harvested from the pastures with a low soil $\mathrm{pH}, 52$ per cent of the forage from pastures with a medium soil $\mathrm{pH}$ and 59 per cent of the forage from pastures with a high soil $\mathrm{pH}$.

Amounts of digestible dry matter and crude protein harvested in 1963 from the nine pastures are given in Table 5 . Treated pastures on the average produced 520 pounds more digestible dry matter per acre than did the control pastures from which 451 pounds of digestible dry matter per acre were harvested. Treated pastures produced 230 pounds of crude protein per acre as compared with 93 pounds from the control pastures. Both of these evaluations show that greater benefits were derived from fertilization than was indicated by dry-matter yields. Furthermore, observations in the field indicated that animal preference was greater for the fertilized forage than for the unfertilized forage. In fact, on the high $\mathrm{pH}$ Westmoreland pasture, animals did not consume untreated forage until the fertilized area was completely grazed.

As a result of fertilization, the production of digestible dry matter and crude protein was increased by more than 100 per cent on all pastures except those on the medium pH Gilpin soil and the low pH Westmore- 


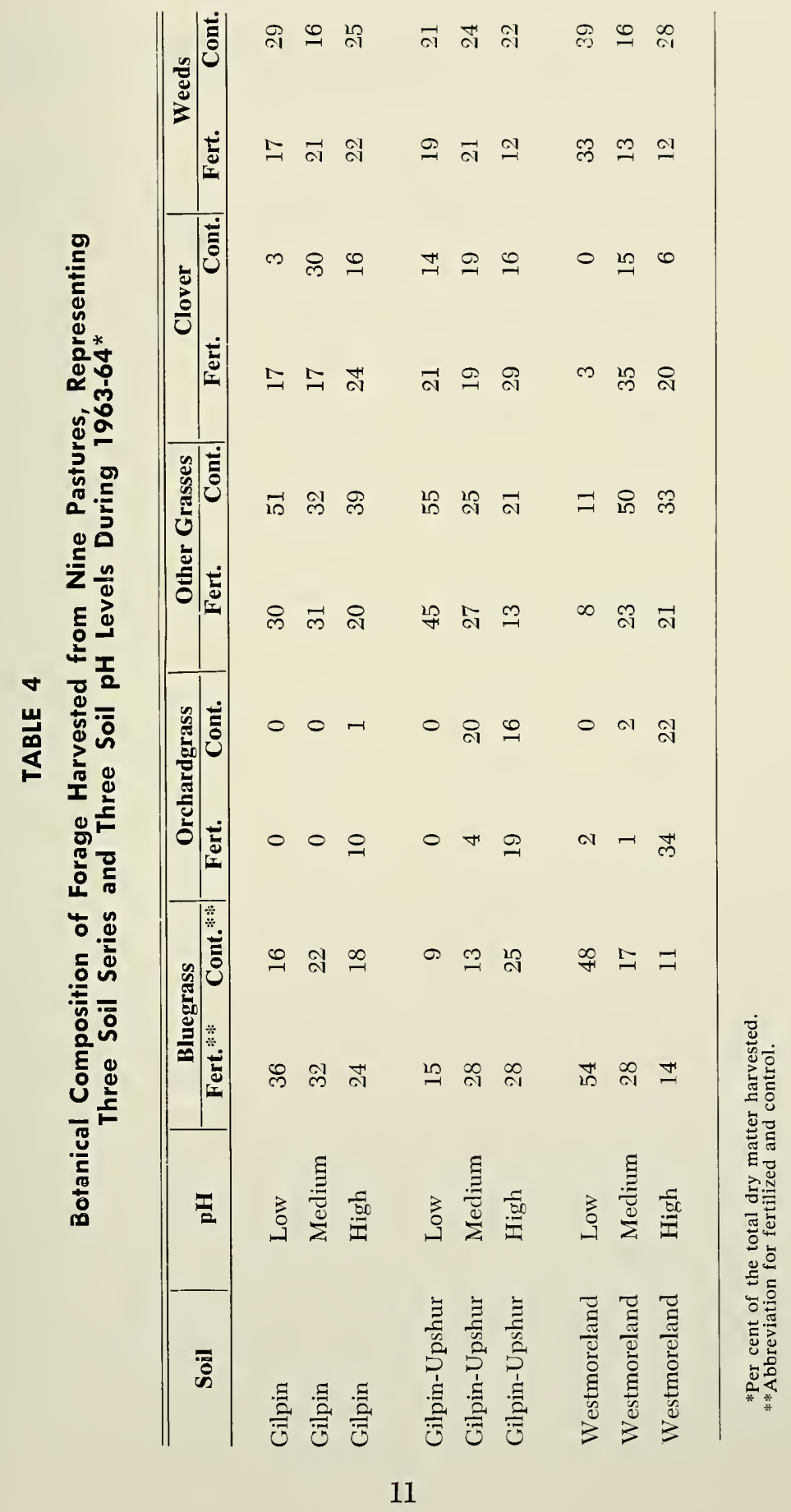


TABLE 5

Digestible Dry Matter and Crude Protein Harvested in 1963 From Nine Pastures, Representing Three Soil Series and Three pH Levels, Under Two Fertility Levels

\begin{tabular}{|c|c|c|c|c|c|}
\hline \multirow[t]{2}{*}{ Soil } & \multirow[t]{2}{*}{ pH } & \multicolumn{2}{|c|}{$\begin{array}{c}\text { Digestible D.M. } \\
\text { (lbs. per Acre) }\end{array}$} & \multicolumn{2}{|c|}{$\begin{array}{l}\text { Crude Protein } \\
\text { (lbs. per Acre) }\end{array}$} \\
\hline & & Fertilized & Control & Fertilized & Control \\
\hline Gilpin & Low & 980 & 480 & 206 & 86 \\
\hline Gilpin & Medium & 820 & 520 & 188 & 104 \\
\hline Gilpin & High & 820 & 360 & 198 & 70 \\
\hline Gilpin-Upshur & Low & 820 & 380 & 198 & 74 \\
\hline Gilpin-Upshur & Medium & 720 & 260 & 180 & 50 \\
\hline Gilpin-Upshur & High & 1700 & 800 & 374 & 166 \\
\hline Westmoreland & Low & 560 & 400 & 126 & 80 \\
\hline Westmoreland & Medium & 1220 & 400 & 308 & 94 \\
\hline Westmoreland & High & 1100 & 460 & 294 & 116 \\
\hline \multicolumn{6}{|l|}{ Averages: } \\
\hline Gilpin & & 873 & 453 & 197 & 87 \\
\hline Gilpin-Upshur & & 1080 & 480 & 251 & 97 \\
\hline Westmoreland & & 960 & 420 & 243 & 97 \\
\hline & Low & 787 & 420 & 177 & 80 \\
\hline & Medium & 920 & 393 & 225 & 83 \\
\hline & High & 1207 & 540 & 289 & 117 \\
\hline All Pastures & & 971 & 451 & 230 & 93 \\
\hline
\end{tabular}

land soil. Of the control plots, those on the medium $\mathrm{pH}$ Gilpin soil produced the second largest amount of digestible dry matter. The crude protein data indicate that the plants in the treated plots of this pasture did receive nitrogen, but only a $5 S$ per cent increase in digestible dry matter and an 81 per cent increase in crude protein were observed. These increases were only half as large as those observed for the other locations. Based on these results, it appears that the smaller increases in digestible dry matter and crude protein were related to the higher content of clover in the control plots. Large amounts of growth in the first harvest (because of being undergrazed) from both the treated 
and control plots on the low pH Westmoreland soil, as well as the lack of legumes in these plots, may account for the small increases in digestible dry matter and crude protein.

Response to fertilization for the Gilpin soil was inferior to that of the Gilpin-Upshur soil and Westmoreland soil in the production of both digestible dry matter and crude protein. The average increase in digestible dry matter and protein production due to fertilization became greater as $\mathrm{pH}$ increased. However, the highest soil $\mathrm{pH}$ readings were recorded for the high $\mathrm{pH}$ Gilpin soil, whereas production from the treated plots on this pasture rated only a tie for fifth place among all the pastures, and the control plots produced the second lowest yields recorded.

The information presented above raises at least three questions: (a) Were environmental conditions (especially soil moisture) more favorable for plant growth at some locations than at others? (b) How accurate were the aerial applications of fertilizer? and (c) Did the difference in white clover content of the pastures result in an unfair comparison among pastures?

Answers to these questions were sought by assessing the effect of fertilizer on productivity under uniform environmental conditions. Fertilizer was applied uniformly to 6 of 12 pots containing plugs which had been removed from the field control areas in each pasture. The growth of these fertilized plants was compared with the growth of unfertilized plants in the other 6 pots under uniform temperature, light, and moisture conditions. An aggressive growth of clover on the treated plugs from the high $\mathrm{pH}$ Westmoreland soil resulted in both large yields of forage and the largest yield increase due to fertilization. The growth of clover appeared to be favored over the growth of grass under the conditions of this experiment. Plants from the medium $\mathrm{pH}$ Westmoreland soil responded least to the application of fertilizer. This response was unlike that observed in the field and was associated with a relatively poorer performance of the treated plugs and a relatively better performance of the control plugs than was obtained with plants in the field. The difficulty of selecting uniform plugs with a representative botanical composition may, however, account for the variation in this and other responses. Nevertheless, increases in yield ranging from 21 to 193 per cent resulted from fertilization, and the average yield increase was 90 per cent which compares favorably with the response (103) obtained in the field in 1963. Furthermore, total dry weight for four cuttings from the plugs was significantly correlated with the 1963 ( 5 per cent level) and 1964 ( 1 per cent level) yields.

Two other methods were used to determine whether fertilizer was applied by the aircraft on the field plots. Examination of the covers 
placed over control areas indicated that in every instance fertilizer was deposited on the pastures. The other method involved the measurement of fertilizer that fell in buckets placed between the areas designated for the treated and control plots. Fertilizer collected in this manner indicated that an average of 250 pounds per acre was applied. Some variability in fertilizer collected among farms was noted, but this may be explained, at least in part, by the various angles at which the plane was flying in relation to the hillside (and buckets) when the fertilizer was applied. An important finding, however, was that there was little relationship $(\mathrm{r}=.32)$ between the amount of fertilizer collected and yield response to fertilization in 1963. If the bucket technique was valid for estimation of fertilizer deposition, the low correlation suggests that in addition to fertilizer, other factors affected yield responses.

With regard to the third question, it is pertinent to point out that the amount of clover in the nine pastures varied from zero to 46 per cent of the total dry weight during the two-year period. After the effects of the nitrogen fertilizer disappeared, pasture productivity would depend on phosphorus availability and the abundance of clover. Without a legume to provide nitrogen, only small yield increases could be expected even if phosphorus were available for plant growth. To answer question three, white clover seed was broadcast over the surface of every plug after four harvests were obtained from the plugs and then two more harvests were taken (Table 6). The seeding of clover, therefore, permitted comparisons in which the absence of clover was not considered as limiting the growth of grasses. The addition of clover resulted in higher yields for most of the fertilized and control plugs. The increase, however, was larger for the fertilized plugs than for the controls. Plugs from three pastures, i.e., medium $\mathrm{pH}$ Gilpin soil, high $\mathrm{pH}$ Gilpin-Upshur soil, and medium $\mathrm{pH}$ Westmoreland soil were affected much more than were the other six. The effect of the clover being added was sufficiently great to completely change the productivity ranking of the plugs. Dry-weight yields from the fourth cutting (before clover seeding) were significantly ( 5 per cent level) correlated with yields of the fifth cutting but were not correlated with yields of the sixth cutting, whereas yields from the fiith and sixth cuttings were highly correlated ( 1 per cent level). The appearance of the clover was not uniform (Table 7 ). Fertilizer had virtually no effect on clover appearance, whereas soil type and $\mathrm{pH}$ did. On the average, the highest percentage of healthy clover was found on the Cilpin soil and the least on the Gilpin-Upshur soil, whereas the reverse was true for the unthrifty clover plants. More than three times as many plugs containing healthy clover plants were found among the high $\mathrm{pH}$ plugs than the low $\mathrm{pH}$ plugs and the reverse was true for 
TABLE 6

Dry Matter Harvested from Fertilized and Unfertilized Plugs, Representing Three Soil Series and Three pH Levels and Grown Under Uniform Conditions

\begin{tabular}{|c|c|c|c|c|c|}
\hline \multirow[b]{2}{*}{ Soil } & \multirow[b]{2}{*}{ pH } & \multicolumn{4}{|c|}{ Yield (mg. dry matter per plug) } \\
\hline & & \multicolumn{2}{|c|}{$\begin{array}{l}\text { Before adding clover seed } \\
\text { Fertilized } \\
\text { Control }\end{array}$} & \multicolumn{2}{|c|}{ After adding clover seed } \\
\hline Gilpin & Low & $479^{*}$ & 190 & $939^{* *}$ & 577 \\
\hline Gilpin & Medium & 405 & 178 & 1546 & 959 \\
\hline Gilpin & High & 451 & 235 & 808 & 592 \\
\hline Gilpin-Upshur & Low & 544 & 341 & 590 & 549 \\
\hline Gilpin-Upshur & Medium & 415 & 308 & 536 & 657 \\
\hline Gilpin-Upshur & High & 426 & 215 & 1530 & 562 \\
\hline Westmoreland & Low & 333 & 181 & 946 & 425 \\
\hline Westmoreland & Medium & 423 & 351 & 1823 & 1433 \\
\hline IVestmoreland & High & 895 & 305 & 1404 & 641 \\
\hline
\end{tabular}

Averages:

Gilpin

445

$201 \quad 1098$

709

Gilpin-Upshur

462

288

885

589

IVestmoreland

550

279

1391

833

$\begin{array}{ll}\text { Low } & 452 \\ \text { Medium } & 414 \\ \text { High } & 591\end{array}$

237

825

517

278

1301

1016

252

1247

598

All Plugs

486

256

1125

710

*Average weight for four cuttings and 6 replications.

***Average weight for two cuttings and 6 replications.

the distribution of the unthrifty clover plants. This undoubtedly could affect or be associated with nodulation which in turn would affect the nitrogen supply for grasses. More information is needed to better understand factors limiting clover growth because, as demonstrated in these studies, clover is a key factor in pasture productivity. The data also suggest that consideration should be given to the possibility of including clover seed with aerial applications of fertilizer when the clover content of the pastures being fertilized is low. 


\section{TABLE 7}

\section{Appearance of Clover Plants Growing on Soils Representing Three Soil Series and Three pH Levels}

\begin{tabular}{|c|c|c|c|c|}
\hline \multirow[b]{2}{*}{ Soil } & \multirow[b]{2}{*}{ pH } & \multicolumn{3}{|c|}{ Appearance of Clover Plants } \\
\hline & & Thrifty & Intermediate & Unthrifty \\
\hline Gilpin & Low & $5^{*}$ & 5 & 2 \\
\hline Gilpin & Medium & 7 & 5 & 0 \\
\hline Gilpin & High & 8 & 4 & 0 \\
\hline Gilpin-Upshur & Low & 2 & 6 & 4 \\
\hline Gilpin-Upshur & Medium & 0 & 7 & 5 \\
\hline Gilpin-Upshur & High & 6 & 4 & 2 \\
\hline Westmoreland & Low & 0 & 6 & 6 \\
\hline Westmoreland & Medium & 7 & 4 & 1 \\
\hline Westmoreland & High & 9 & 1 & 2 \\
\hline \multicolumn{5}{|l|}{ Totals: } \\
\hline Gilpin & & 20 & 14 & 2 \\
\hline Gilpin-Upshur & & 8 & 17 & 11 \\
\hline \multirow[t]{4}{*}{ Westmoreland } & & 16 & 11 & 9 \\
\hline & Low & 7 & 17 & 12 \\
\hline & Medium & 14 & 16 & 6 \\
\hline & High & 23 & 9 & 4 \\
\hline
\end{tabular}

* Number includes both fertilized and unfertilized plugs. No effect of fertilizer was noted on clover appearance.

\section{SUMMARY}

EXPERIMENTS were designed to measure and evaluate the response E of hill pastures, varying in soil series and soil $\mathrm{pH}$, to fertilizer applied from an airplane. Dry-matter yields over a two-year (one dry year) period, resulting from a single application of fertilizer, varied from .19 tons per acre to 1.37 tons per acre. Only two pastures had dry-matter increases of less than .50 tons per acre. The small responses were thought to be associated with a lower clover content of the treated plots than the controls (medium pH Gilpin soil) or to the nature of the soil and 
previous management (low $\mathrm{pH}$ Westmoreland soil-Guernsey soil). Increases in dry-matter yield were highest for the Westmoreland soil and high $\mathrm{pH}$ soils and were lowest for the Gilpin soil and low pH soils. The Westmoreland soil produced 64 per cent more forage on the average than did the Gilpin soil, and the high $\mathrm{pH}$ soils produced 108 per cent more forage than did the low $\mathrm{pH}$ soils. Botanical composition of the pastures was affected more by soil $\mathrm{pH}$ than by soil series. Dry-matter yields were highly correlated with the percentage of clover in the plots during the second year and therefore nitrogen became a limiting factor for the growth of grasses in some pastures. Both field observations and laboratory measurements indicated that forage from the fertilized pastures had a higher nutritive value than did forage from the untreated pastures.

\section{BIBLIOGRAPHY}

1. Bear, F. E. and Salter, R. M. Analyses of One Hundred West Virginia Soils. W. Va. Univ. Agr. Expt. Sta. Bull. 161. 1916.

2. Brown, B. A. "The Chemical Composition of Pasture Species of the Northeast Region as Influenced by Fertilizers.” Jour. Am. Soc. Agron. 32: 256-265. 1940.

3. Brown, B. A., and Munsell, R. I. "Grasses Fertilized with Nitrogen Compared with Legumes for Hay and Pasture." Jour. Am. Soc. Agron. 35: 811-816. 1943.

4. Brown, B. A., Munsell, R. I., and King, A. V. Fertilization and renovation of grazed permanent pastures. Storrs Agr. Expt. Sta. (Conn.) Bull. 350. 1960.

5. Brown, E. M. Some effects of temperature on the growth and cliemical composition of certain pasture grasses. Mo. Agr. Expt. Sta. Res. Bull. 299. 1939.

6. Bryan, O. C. and Deatrick, E. P. Chemical analyses and fertility of West Virginia soils. IV. Va. Univ. Agr. Expt. Sta. Bull. 184. 1924.

7. Chiasson, T. C. "The Effects of Various Increments of $\mathrm{N}, \mathrm{P}$, and $\mathrm{K}$ on the Yield and Botanical Composition of Permanent Pastures." Can. Jour. Plant Sci. 40: 235-247. 1960.

8. Eheart, J. F., and Ellett, W. B. The effects of certain nitrogenous fertilizers on the chemical and vegetative composition and yicld of pasture plants. Va. Agr. Expt. Sta. Bull. 75. 1941.

9. Eheart, J. F., and Pratt, A. D. The digestibility and utilization by dairy cows of nutrients from fertilized and unfertilized bluegrass pasture. Va. Agr. Expt. Sta. Tech. Bull. 81. 1942.

10. Ellenberger, H. B., Newlander, J. A., and Jones, C. H. Yield and composition of pasture grass. Vt. Agr. Expt. Sta. Bull. 295. 1929.

11. Enlow, C. R., and Coleman, J. M., "Increasing the Protein Content of Pasture Grasses by Frequent Light Applications of Nitrogen.” Jour. Am. Soc. Agron. 21: 845-853. 1929. 
12. Jung, G. A., Lilly, B., Shih, S. C., and Reid, R. L. "Studies with Sudangrass. 1: Effect of growth stage and level of nitrogen fertilizer upon yield of dry matter; estimated digestibility of energy, dry matter and protein; amino acid composition; and prussic acid potential." Agron. Jour. 56: 537-542. 1964.

13. Lutz, J. A., Obenshain, S. S., and Lillard, J. H. The influence of fertilization and irrigation on the quantity and quality of pasture herbage. Va. Agr. Expt. Sta. Bull. 543. 1962.

14. Midgley, A. R., and Weiser, V. L. Need and use of potash on Vermont pasture. Vt. Agr. Expt. Sta. Bull. 403. 1936.

15. Mortimer, G. B., and Ahlgren, H. L. "Influence of fertilization, irrigation, and stage and height of cutting on yield and composition of Kentucky bluegrass (Poa pratensis L.)." Jour. Am. Soc. Agron. 28: 5̃15-533. 1936.

16. Mott, G. O. "Effectiveness of fertilization and management in increasing yields of pastures in Indiana." Soil Sci. Soc. of Am. Proc. 8: 276-281. 1943.

17. O'Brien, R. E., and Obenshain, S. S. The effect of different phosphatic fertilizers on the yield, plant population, and chemical composition of pasture herbage on Dunmore and Emory Soils. Va. Agr. Expt. Sta. Tech. Bull. 80. 1942.

18. Odlınd, T. E., Wilson, C. V., Henderson, H. O., and Deatrick, E. P. Pasture Experiments. W. Va. Univ. Agr. Expt. Sta. Bull. 235. 1930.

19. Pierre, WT. H., Longwell, J. H., Robinson, R. R., Browning, G. M., McKeever, Ivan, Copple, R. F. West Virginia Pastures: Type of vegetation, carrying capacity and soil properties. W. Va. Univ. Agr. Expt. Sta. Bull. 280. 1937.

20. Pierre, W. H., and Robinson, R. R. "The calcium and phosphorus content of pasture herbage and of various pasture species as affected by fertilization and liming." Jour. Am. Soc. Agron. 29: 477-497. 1937.

21. Pohlman, G. G., and Comell, F. D. Pasture Improvement in Upshur County. IV. Va. Univ. Agr. Expt. Sta. Bull. 308. 1943.

22. Ramage, C. H., Eby, C., Mather, R. E., and Purvis, E. R. "Yield and Chemical Composition of Grasses Fertilized Heavily with Nitrogen." Agron. Jour. 50: 59-62. 1958.

23. Reid, R. L., Jung, G. A., and Murray, S. "The Measurement of Nutritive Quality in a Bluegrass Pasture Using in vivo and in vitro Techniques." Jour. Animal Sci. 23: 700-710. 1964.

24. Robinson, R. R., and Pierre, W. H. Response of permanent pastures to lime and fertilizers (1930 to 1936). WV. Va. Univ. Agr. Expt. Sta. Bull. 289. 1938.

25. Robinson, R. R., and Pierre, W. H. "The Effect of Nitrogen Fertilization of Permanent Pastures on Seasonal Distribution of Yields and on Nitrogen Recovery in the Herbage." Jour. Am. Soc. Agron. 34: 747-764. 1942.

26. Robinson, R. R., and Sprague, V. G. "The Clover Populations and Yields of a Kentucky Bluegrass sod as Affected by Nitrogen Fertilization, Clipping Treatments, and Irrigation." Jour. Am. Soc. Agron. 39: 107-116. 1947. 
27. Schaller, F. IV., and Pohlman, G. G. The effect of rate and frequency of phosphate application on pasture production. W. Va. Univ. Agr. Expt. Sta. Bull. 380. 1955.

28. Schaller, F. W., Pohlman, G. G., Henderson, H. O., and Ackerman, R. A. Pasture fertilization experiments at Reymann Memorial Farm. IV. Va. Univ. Agr. Expt. Sta. Bull. 324. 1945.

29. Skinner, J. J., and Noll, C. F. "Botanical Composition of a Permanent Pasture as Influenced by Fertilizers of Different Composition." Soil Sci. 7: 161-179. 1919.

30. Sullivan, E. F. "Effects of Soil Reaction, Clipping Height, and Nitrogen Fertilization on the Productivity of Kentucky Bluegrass Sod Transplants in Pot Culture. Agron. Jour. 54: 261-263. 1962.

31. Sivift, R. IV., Cowan, R. L., Ingram, R. H., Maddy, H. K., Barron, G. P., Grose, E. C., and Washko, J. B. "The Relative Nutritive Value of Kentucky Bluegrass, Timothy, Bromegrass, Orchard Grass and Alfalfa." Jour. Animal Sci. 9: 363-372. 1950.

32. Vinall, H. N., and Wilkins, H. L. "The Effect of Fertilizer Applications on the Composition of Pasture Grasses.” Jour. Am. Soc. Agron. 28: 562-569. 1936. 




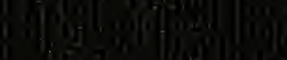

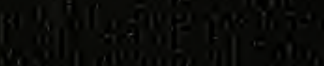

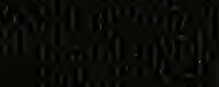

wions

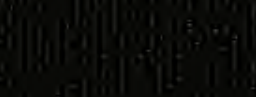

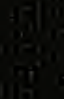

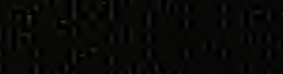

(m)

(5)

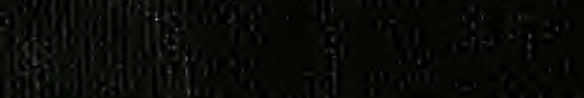

